\title{
Relationship of Dorsoventral Eyeshine Distributions to Habitat Depth and Animal Size in Mesopelagic Decapods
}

\author{
M. L. JOHNSON ${ }^{1 * *}$, P. M. J. SHELTON ${ }^{1}$, E. GATEN ${ }^{1} \pitchfork$, AND P. J. HERRING $^{2}$ \\ ${ }^{1}$ Department of Biology, University of Leicester, University Road, Leicester LE1 7RH, UK; and \\ ${ }^{2}$ Southampton Oceanography Centre, Empress Dock, Southampton SOI4 3ZH, UK
}

\begin{abstract}
Eyeshine distribution patterns recorded from the eyes of 19 mesopelagic decapod species were examined and related to the depths at which the species are found. For most species examined, eyeshine was found to be brighter ventrally than dorsally. Deep-water decapod species that do not undergo diel vertical migrations had brighter dorsal eyeshine than migratory species. Eyeshine intensity increased with body size in five of the species examined and decreased in two. These changes in eyeshine intensity may be an adaptation to variations in depth distributions that occur with increasing body size. It is suggested that the depth and size-related changes reflect the importance of remaining camouflaged in the mesopelagic realm and are an example of ecologically functional development.
\end{abstract}

\section{Introduction}

Many species active at low light levels possess a welldeveloped reflective tapetum behind the retina that effectively doubles the path length of light through the photoreceptor cells (Lythgoe, 1979). This doubling increases the photon-capturing efficiency of the eye without requiring an increase in eye size (Land, 1981). In most arthropod species that have superposition compound eyes, light reflected by the tapetum and not absorbed by the rhabdoms is visible as eyeshine (Kunze, 1979). Eyeshine consists of a circular patch of light that fills about half of the eye and represents the effective aperture (Land, 1981). Since approximately $80 \%-90 \%$ of the blue-green light entering the eye is ab-

\footnotetext{
Received 18 February 2000; accepted 12 June 2000.

* Present address: Biology Department, University of Hull, (Scarborough Campus), Filey Road, Scarborough, YOll 3ZZ, UK

† To whom correspondence should be addressed. E-mail: gat@le.ac.uk
}

sorbed by the rhabdoms (Johnson, 1998), eyeshine is orange-red when the eye is illuminated with white light.

The ecology of the mesopelagic realm is dominated by the vertical distribution of its inhabitants (Herring and Roe, 1988). Few expeditions have comprehensively studied the way in which species are distributed in the water column in a particular area over any significant length of time. As a result, we have little knowledge of how ecological factors affect vertical distributions and daily vertical migrations. In addition, the picture is complicated by community variation and differences in migratory behavior that may be associated with factors such as the intensity and angular distribution of light, hydrography, season, reproduction, ontogeny, feeding, interspecific interactions, and capture methods (Foxton, 1970; Jerlov, 1974; Longhurst, 1976; Marshall, 1979; Roe, 1984; Domanski, 1985; Herring and Roe, 1988; Gonzalez et al., 1997). Our knowledge of mesopelagic ecology is derived for the most part from spot samples taken at various unrelated locations, seasons, and times of day. These samples have demonstrated that, although there are clear underlying patterns of diurnal behavior (Foxton, 1970), the preferred depths for all species are highly variable.

For many deep-sea species, shielding and reflecting pigments in the eye probably do not move in response to changes in light intensity (Nilsson, 1982; Shelton et al., 1986). In addition, previous studies have suggested that, as with some nocturnal insects (Laughlin and Weckström, 1993), deep-water decapods may lack the physiological gain-control mechanisms necessary for light adaptation (Nilsson and Lindström, 1983; Johnson et al., 2000). Mesopelagic species are thus limited by the range of light intensities in which their eyes can function, and they must migrate to avoid downwelling light intensities that exceed 
their physiological limits. Therefore, given the structured way in which light varies with depth (Kirk, 1983) and the fact that the dynamic range of the eyes dictates to some degree the depths inhabited, the eyes of mesopelagic decapods should show physiological and anatomical associations with their preferred depth.

Here we suggest that, with respect to sensitivity, the ideal eye would have a complete tapetum equally reflective in all regions. Such an eye would have uniform sensitivity in all regions. However, in an earlier study of selected mesopelagic shrimps, it was found that tapeta are often incomplete or have regional variations in their reflectivity (Shelton $e t$ al., 1992). This is in spite of the fact that such animals live in a dim environment where bioluminescence plays a major role in inter- and intra-specific communication (Burkenroad, 1943; Herring, 1990; Morin and Cohen, 1991) and where maximizing sensitivity must be of considerable importance. It was concluded that any reduction in reflectivity must be an adaptation to reduce visibility to predators. It was shown that in many species there is a decreasing gradient of eyeshine intensity along the anteroposterior axis of the eye. In other cases there is a large hole in the tapetum. The anteroposterior gradient seems to be associated with reducing the visibility of the shrimp to predators during the escape response. At such times, the eye swings forward so that the least reflective part of the eye is exposed to the predator (Shelton et al., 2000).

We set out to investigate the features of eyeshine in mesopelagic decapods and to suggest how the variations found may be related to their life history and depth distribution. The current paper investigates differences in reflectivity along the dorsoventral axis of a range of mesopelagic shrimps. It was found that, as with the anteroposterior axis, there are considerable differences in reflectivity between dorsal and ventral regions. We conclude that the design of the eye in mesopelagic species is constrained by competing factors - the need to see and the need to avoid being seen.

\section{Materials and Methods}

Shrimps were taken from depths of between 0 and $2250 \mathrm{~m}$ during RRS Discovery cruise 204 (1995) in the eastern Atlantic north of the Cape Verde Islands $\left(25^{\circ} \mathrm{W}\right.$, $20^{\circ} \mathrm{N}$ ). The use of an RMT $1+8$ net system allowed sampling at discrete depths, and a closing cod-end maintained animals in good condition while they were brought to the surface (Roe and Shale, 1979; Wild et al., 1985). Lightinduced damage of the eye was prevented, and the general condition of the animals was maintained by sorting and storing them in dim red light and placing them in refrigerated aquaria until required. All were utilized within $2 \mathrm{~h}$ of capture.

Mesopelagic species can be split broadly into two groups: those that undergo diel vertical migrations and those that live in deep water and do not migrate (Fig. 1). Species such as Sergestes corniculum, Oplophorus spinosus, Parapandalus richardi, and Systellaspis debilis are generally found above $1000 \mathrm{~m}$ and migrate close to the surface at night (Hiller-Adams and Case, 1988; Cartes et al., 1994; Institute of Oceanographic Sciences (IOS) Database). Other species such as Acanthephyra pelagica, Gennadas valens, and Sergia robustus undergo diel vertical migrations of less magnitude and are rarely caught above $300 \mathrm{~m}$ (Domanski, 1985; Hiller-Adams and Case, 1988; IOS Database). Systellaspis cristata, Acanthephyra gracilipes, and Bentheogennema intermedia are examples of virtually nonmigratory species that are generally found between 700 and $1000 \mathrm{~m}$ (Domanski, 1985; IOS Database).

Eyeshine distribution and intensity was examined using a variation of the protocol developed by Shelton et al. (1992). Shrimps were mounted on a rotatable rod projecting into a polythene chamber filled with chilled seawater. The chamber was sealed with a glass coverslip to prevent distortion of the image by water surface movement. Measurements were carried out only on animals that had eyestalks in the laterally extended position, as they are during normal forward swimming. The preparation was examined through a Zeiss binocular microscope with a video camera attachment, and illumination was provided by a Schott KL 1500 halogen light source. The microscope was focused and the specimen was manipulated under dim red light. To record eyeshine intensity, preparations were axially illuminated with green (520 nm broadband filter; Wratten No. 59) light via a small mirror oriented at about $45^{\circ}$ to the light beam just outside the field of view. Eyeshine was recorded using a JVC TK-1085E color video camera (with the automatic gain control switched off) and a Panasonic VHS video recorder. The preparation was rotated around the longitudinal axis by $20^{\circ}$ increments from the dorsal to ventral points. For comparison, and to more easily assess any physical damage, the eye was then observed using white light (no filter). Video images were analyzed on a Kontron image analysis system. Average brightness across the eyeshine patch was measured in gray-scale units (1-255 GSU) and the patch diameter measured. Depth distributions were taken from the most appropriate literature or the IOS database. Where the information was available, the mean depth and the $95 \%$ confidence interval for range were used. If only range was available, then the midpoint was taken.

\section{Results}

Eyeshine distribution patterns were observed and recorded from 136 eyes from 19 species (Table 1).

\section{Eyeshine patch diameter}

There were noticeable differences in the diameter of the eyeshine patches under the two different colors of light 


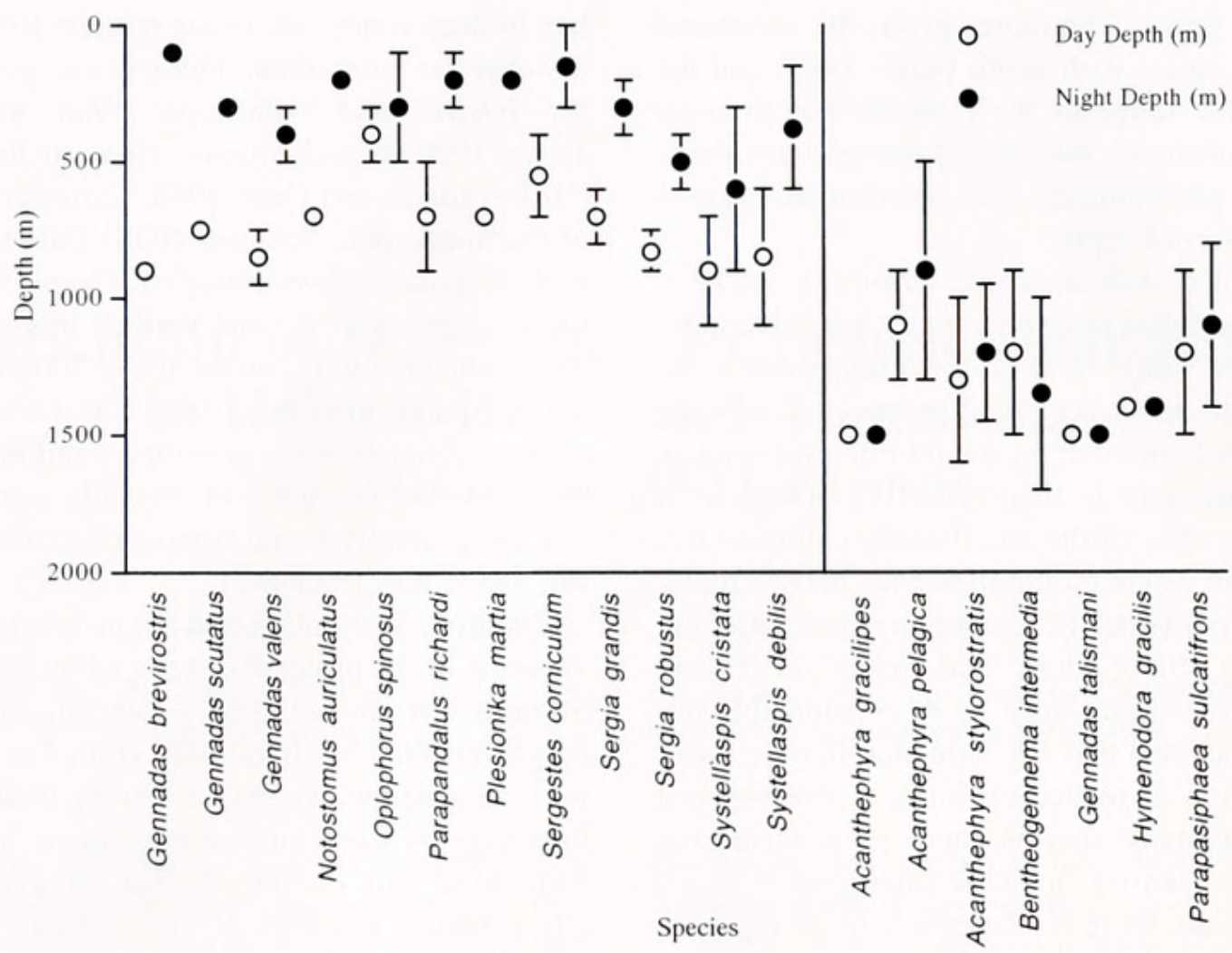

Figure 1. Estimated depth distributions for the 19 species of mesopelagic decapods examined. Data points indicate the mean or midpoint of the range which, when data are available, is indicated by the error bars. The species are separated into two depth classifications depending on their depth distribution and migratory behavior. Those that are commonly found to occur above $1000 \mathrm{~m}$ are classed as migratory. Depth data are from the following sources: Hiller-Adams and Case (1988)_Gennadas valens, Oplophorus spinosus, Parapasiphaea sulcatifrons, Sergia grandis, S. robustus, Systellaspis cristata, S. debilis; Cartes et al. (1994)—Plesionika martia; Crosnier and Forest (1973)—Notostomus auriculatus, Sergestes corniculum; Heffernan and Hopkins (1981)—Gennadas brevirostris, G. scutatus, G. talismani; Domanski (1985)-Acanthephyra pelagica, A. stylorostratis, Bentheogennema intermedia, Parapandalus richardi; Institute of Oceanographic Science database-Acanthephyra gracilipes, Hymenodora gracilis.

used. Generally the eyeshine patch diameter appeared smaller under green light and larger under white light. Often when illuminated with white light, the exact edge of the eyeshine patch was not clear since a band of eyeshine of a different character (color and intensity) would surround the main patch. To allow eyeshine patch diameters resulting from green and white light to be compared, the relative eyeshine patch diameter (eyeshine patch diameter/eye diameter) was calculated. This allowed a better comparison of animals of different sizes. The results of a two-tailed $t$ test of the data from all the species examined suggested that there was a significant difference resulting from illumination by green or white light $(t=10.85, P>0.001, n=$ 128). The relative eyeshine patch diameter resulting from green incident light $(0.33 \pm 0.09 \mathrm{~mm})$ was $27.5 \%$ smaller than that resulting from white light $(0.46 \pm 0.10 \mathrm{~mm})$.

Because there was a significant difference in the diameter of the eyeshine patch under white and green light, this study used only the measurements of diameter and intensity made under green illumination, which more closely resembles the light that mesopelagic species would experience normally (Kirk, 1983).

\section{Eyeshine distribution along the dorsoventral axis}

For the 19 species examined, the general trend is for eyeshine to be brightest ventrally (Table 1). The degree to which eyeshine intensity varies around the eye differs between species. In nonmigratory and deeper-living species, such as Acanthephyra pelagica and Acanthephyra stylorostratis, eyeshine is usually of similar intensity dorsally and ventrally (Fig. 2a). Migratory species that come close to the surface during the night, such as Parapandalus richardi, Plesionika martia (Fig. 2b), Oplophorus spinosus, and Systellaspis debilis (Fig. 2 c, d), have eyeshine that is brighter ventrally than dorsally. In Sergestes corniculum, because it hangs vertically during normal swimming, the eyeshine pattern is offset by $90^{\circ}$ so that the more reflective posterior region of the eye is directed downwards (Shelton et al., 1992). 
Table 1

Eyeshine intensity by size class (carapace length, $\mathrm{mm}$ )

\begin{tabular}{|c|c|c|c|c|c|c|}
\hline Species & $\mathrm{C}$ & $n$ & $0-5$ & $5-10$ & $11-15$ & $16+$ \\
\hline Acanthephyra gracilipes & $\mathrm{N}$ & 2 & & $\begin{array}{l}\mathbf{8 4 . 0} \pm \mathbf{5 . 5} \\
85.8 \pm 7.3\end{array}$ & & \\
\hline Acanthephyra pelagica & M & 8 & $\begin{array}{l}\mathbf{5 0 . 4} \\
78.5\end{array}$ & & $\begin{array}{l}\mathbf{6 8 . 7} \pm \mathbf{1 7 . 5} \\
88.7 \pm 9.8\end{array}$ & $\begin{array}{r}104.5 \pm 7.8 \\
98.3 \pm 6.5\end{array}$ \\
\hline Acanthephyra stylorostratis & $\mathrm{N}$ & 2 & & & & $\begin{aligned} \mathbf{7 8 . 1} & \pm \mathbf{4 . 6} \\
70.53 & \pm 2.3\end{aligned}$ \\
\hline Bentheogennema intermedia & $\mathrm{N}$ & 2 & & & $\begin{array}{l}\mathbf{5 6 . 0} \pm \mathbf{3 . 3} \\
78.4 \pm 14.6\end{array}$ & \\
\hline Gennadas brevirostris & M & 5 & & $\begin{array}{r}42.8 \pm 11.3 \\
110.7 \pm 18.4\end{array}$ & & \\
\hline Gennadas scutatus & M & 3 & & $\begin{array}{l}32.9 \pm \mathbf{4 . 1} \\
54.2 \pm 22.3\end{array}$ & & \\
\hline Gennadas talismani & $\mathrm{N}$ & 3 & & $\begin{array}{l}\mathbf{7 9 . 6} \pm \mathbf{9 . 7} \\
95.5 \pm 36.6\end{array}$ & & \\
\hline Gennadas valens & M & 3 & & $\begin{array}{r}\mathbf{4 5 . 1} \pm \mathbf{1 1 . 4} \\
96.1 \pm 15.3\end{array}$ & & \\
\hline Hymenodora gracilis & $\mathrm{N}$ & 2 & & & $\begin{array}{l}\mathbf{6 3 . 7} \pm \mathbf{4 . 4} \\
72.8 \pm 11.4\end{array}$ & \\
\hline Notostomus auriculatus & M & 4 & & $\begin{array}{l}\mathbf{3 4 . 2} \pm \mathbf{1 . 6} \\
37.2 \pm 6.8\end{array}$ & $\begin{array}{l}25.2 \pm \mathbf{3 . 2} \\
42.1 \pm 6.9\end{array}$ & \\
\hline Oplophorus spinosus & M & 16 & $\begin{array}{l}\mathbf{3 0 . 7} \pm \mathbf{0 . 2} \\
48.1 \pm 10.1\end{array}$ & $\begin{array}{l}\mathbf{3 1 . 2} \pm \mathbf{0 . 7} \\
56.1 \pm 3.3\end{array}$ & $\begin{array}{l}35.8 \pm \mathbf{1 . 4} \\
48.5 \pm 5.7\end{array}$ & $\begin{array}{l}\mathbf{4 8 . 9} \pm \mathbf{9 . 6} \\
48.7 \pm 24.0\end{array}$ \\
\hline Parapandalus richardi & M & 2 & & $\begin{array}{l}\mathbf{2 7 . 9} \pm \mathbf{0 . 9} \\
45.3 \pm 15.7\end{array}$ & & \\
\hline Parapasiphaea sulcatifrons & $\mathrm{N}$ & 2 & & $\begin{array}{l}\mathbf{7 5 . 8} \pm \mathbf{3 . 5} \\
42.1 \pm 0.4\end{array}$ & & \\
\hline Plesionika martia & M & 4 & & & $\begin{array}{l}31.9 \\
46.7\end{array}$ & $\begin{array}{l}\mathbf{3 1 . 1} \pm \mathbf{1 . 1} \\
82.4 \pm 22.1\end{array}$ \\
\hline Sergestes corniculum* & M & 7 & & $\begin{array}{l}33.8 \pm \mathbf{0 . 8} \\
45.7 \pm 8.4\end{array}$ & $\begin{array}{l}\mathbf{3 9 . 6} \pm \mathbf{1 8 . 0} \\
48.6 \pm 5.7\end{array}$ & $\begin{array}{l}30.8 \pm \mathbf{2 . 5} \\
69.9 \pm 19.1\end{array}$ \\
\hline Sergia grandis & M & 7 & & $\begin{array}{l}\mathbf{3 2 . 2} \pm \mathbf{0 . 8} \\
33.5 \pm 0.8\end{array}$ & $\begin{array}{l}\mathbf{3 3 . 1} \\
48.7\end{array}$ & $\begin{array}{l}\mathbf{5 1 . 3} \pm \mathbf{3 . 2} \\
94.8 \pm 9.1\end{array}$ \\
\hline Sergia robustus & M & 4 & & $\begin{array}{l}\mathbf{3 1 . 4} \pm \mathbf{0 . 2} \\
35.5 \pm 0.5\end{array}$ & & $\begin{array}{l}\mathbf{4 0 . 8} \\
46.8\end{array}$ \\
\hline Systellaspis cristata & M & 3 & & $\begin{array}{l}\mathbf{4 3 . 6} \\
82.3\end{array}$ & $\begin{array}{l}\mathbf{6 4 . 3} \\
81.2\end{array}$ & $\begin{array}{l}67.3 \\
74.8\end{array}$ \\
\hline Systellaspis debilis & M & 12 & $\begin{array}{l}33.6 \pm \mathbf{2 . 2} \\
46.0 \pm 4.6\end{array}$ & $\begin{array}{l}\mathbf{3 0 . 8} \pm \mathbf{2 . 7} \\
41.2 \pm 6.0\end{array}$ & $\begin{array}{l}\mathbf{2 8 . 7} \pm \mathbf{1 . 6} \\
34.8 \pm 1.3\end{array}$ & \\
\hline
\end{tabular}

Species have been classified $(\mathrm{C})$ as nonmigratory $(\mathrm{N})$ and migratory $(\mathrm{M})$ according to the depth and distance of their daily vertical migration cycle (Fig. 1). Eyeshine intensity is measured in gray-scale units (GSU).

* For Sergestes corniculum, anterior and posterior eyeshine intensities were used in place of dorsal and ventral (see text).

Animal size, eyeshine intensity, and distribution

Good size ranges ( $>5 \mathrm{~mm}$ range) were obtained for nine species. For five species (Acanthephyra pelagica, Oplophorus spinosus, Sergia grandis, Sergia robustus, and Systellaspis cristata) both dorsal and ventral eyeshine increased with carapace length (Table 1). For two species (Plesionika martia and Sergestes corniculum) there was no clear trend with regard to dorsal eyeshine, but ventral eyeshine was greater in larger specimens. In Notostomus auriculatus and Systellaspis debilis, both dorsal and ventral eyeshine intensity decreased with increasing carapace length. A typical example of eyeshine distribution in large and small specimens is shown by $O$. spinosus (Fig. 2c). S. debilis is unusual in that eyeshine intensity is markedly greater in small specimens than large (Fig. 2d). For four species where size ranges and numbers captured permitted, dorsal eyeshine was plotted against carapace length (Fig. 2 e, f). The two 
a) Non-migrants

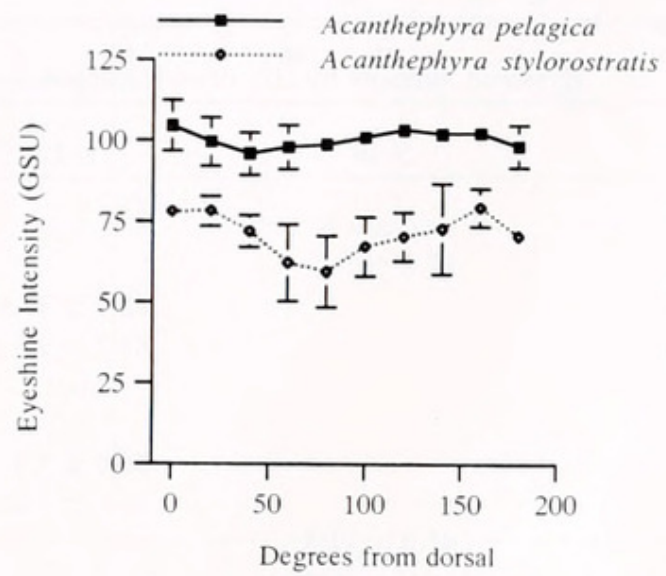

c) Oplophorus spinosus

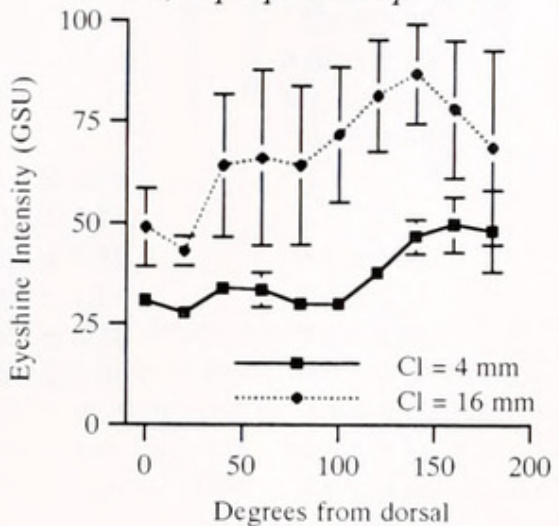

e) Systellaspis debilis \& S. cristata

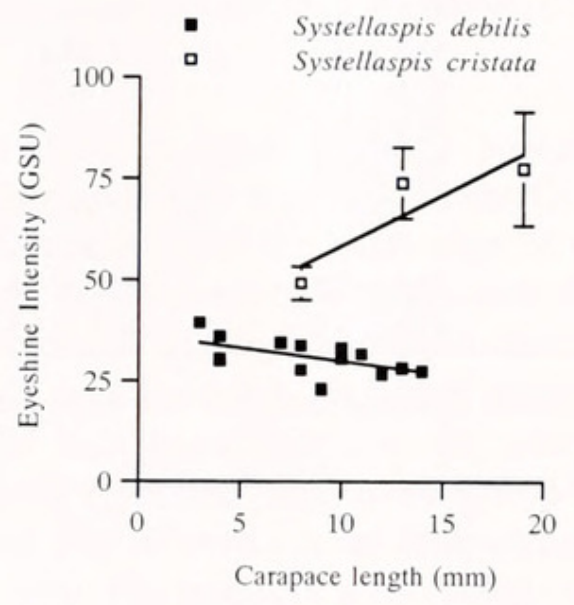

b) Migrants

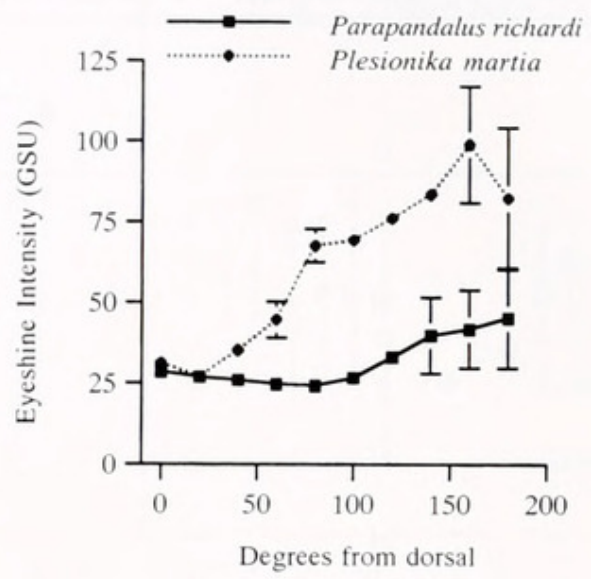

d) Systellaspis debilis

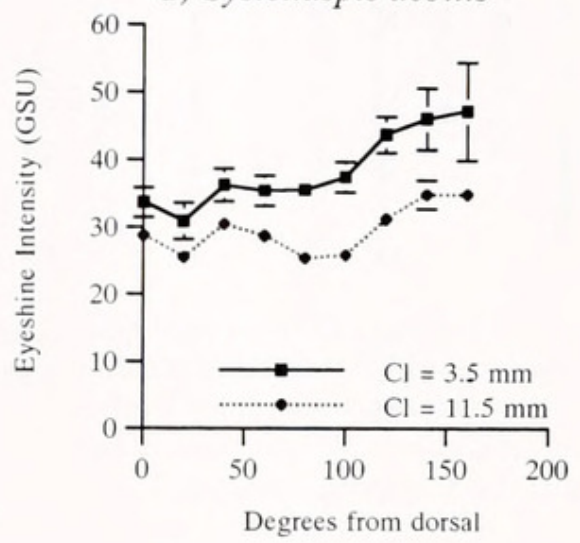

f) Oplophorus spinosus \& Acanthephyra pelagica

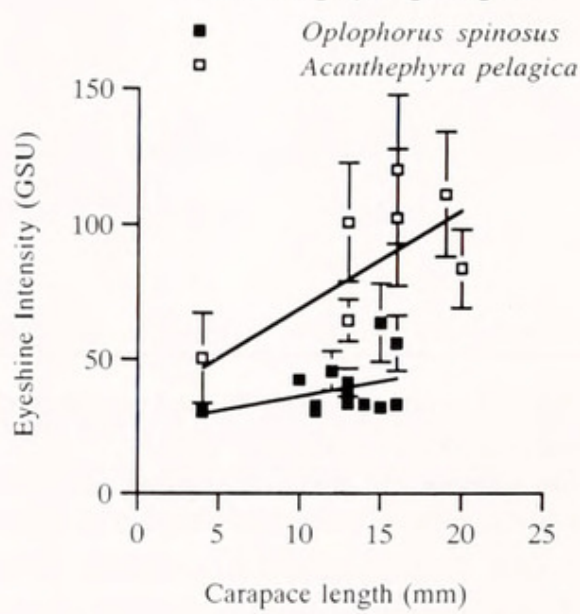

Figure 2. Size- and depth-related variations in eyeshine distributions. (a, b) Dorsoventral eyeshine intensity distributions for four species of decapod. In the two migratory species Parapandalus richardi and Plesionika martia, eyeshine intensity is markedly brighter ventrally than dorsally. In the deep migratory (Acanthephyra pelagica) and nonmigratory (A. stylorostratis) species, eyeshine does not vary significantly from dorsal to ventral. (c, d) Dorsoventral eyeshine distributions for two species of migratory decapod showing how eyeshine intensity differs between large and small specimens. In Oplophorus spinosus, eyeshine is brightest in large specimens. In Systellaspis debilis, eyeshine is brightest in smaller specimens. (e, f) Changes in dorsal eyeshine intensity with increasing carapace length for four species of mesopelagic decapod. For two species (Systellaspis cristata and Oplophorus spinosus), positive and significant correlations were found ( $n=3, r=0.896, P<0.05$ and $n=16, r=0.459, P<0.10$ respectively). Although a positive trend is also found for Acanthephyra pelagica $(n=8, r=0.614)$, it is not significant. In the case of Systellaspis debilis, dorsal eyeshine intensity decreases with increasing carapace length $(n=15, r=0.560, P<0.05)$. 
deep-water species (Acanthephyra pelagica and Systellaspis cristata) showed a significant increase in dorsal eyeshine intensity with increasing carapace length. In Oplophorus spinosus, the increase in dorsal eyeshine intensity was less pronounced, and in Systellaspis debilis, as is also demonstrated by Figure $2 \mathrm{~b}$, eyeshine actually decreased with increasing carapace length.

\section{Depth distribution and eyeshine intensity}

In the present study it was found that for the largest size classes of each of the 19 species examined (Table 1), there were significant correlations between $\log _{10}$ depth and $\log _{10}$ dorsal eyeshine intensity (Fig. 3 a, b). In the case of the relationship between eyeshine intensity and daytime depth, the correlation was markedly improved when Oplophorus spinosus was excluded from the analysis. This species has much higher dorsal eyeshine intensity for its daytime depth distribution than would normally be expected. It is possible that this anomaly is related to the unusually small amplitude of its vertical migration pattern (Foxton, 1970), which suggests that this species may be able to light adapt (thereby reducing eyeshine) to some degree. Ventral eyeshine appears to vary independently of depth (Fig. 3 c, d). Analysis of variance showed that migratory species have significantly lower $(F=3.12, P=0.095) \log _{10}$ dorsal eyeshine intensity $(1.69 \pm 0.21, n=13)$ than nonmigrants $(1.85 \pm 0.15, n=$ 6). A comparison of ventral eyeshine between the two groups showed that there was no significant difference $(F=$ $2.29, P=0.15)$ between migratory $(1.81 \pm 0.14)$ and nonmigratory species $(1.92 \pm 0.15)$.

\section{Discussion}

Eyeshine intensity varies as a result of the efficiency and quantity of reflecting and absorbing pigments within the eye (Gaten et al., unpubl.). Our examination of mesopelagic decapods has demonstrated that the distribution patterns of their dorsoventral eyeshine intensity vary with the species' estimated habitat depths. With increasing habitat depth, a) Day depth v. Dorsal eyeshine intensity

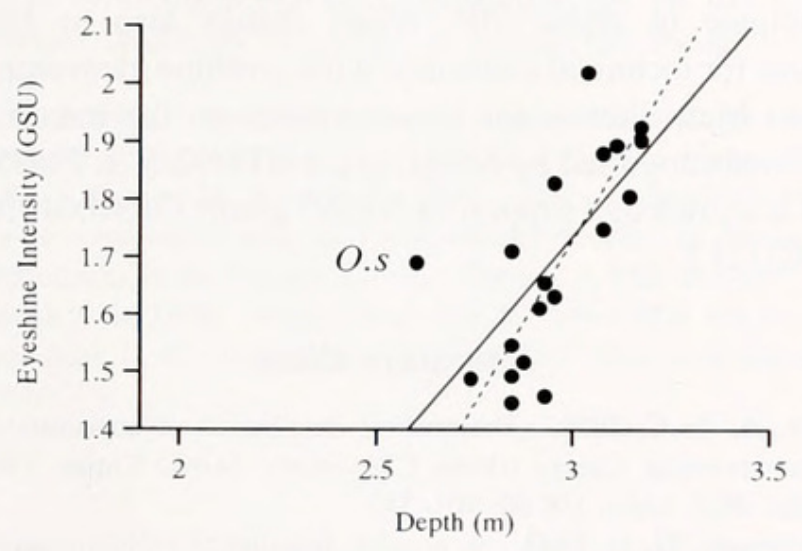

c) Day depth v. Ventral eyeshine intensity

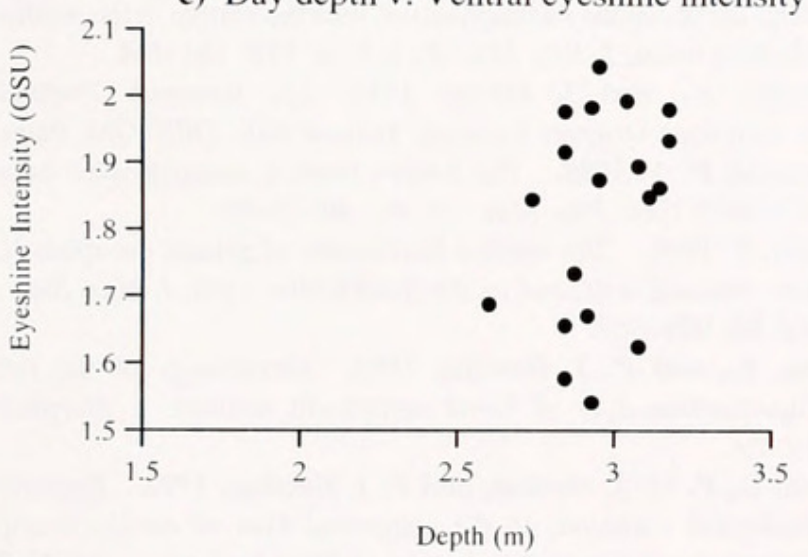

b) Night depth v. Dorsal eyeshine intensity

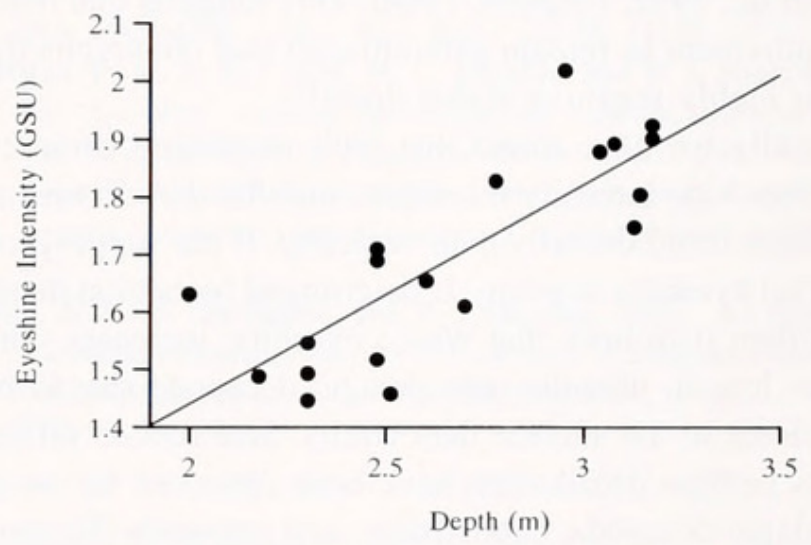

d) Night depth v. Ventral eyeshine intensity

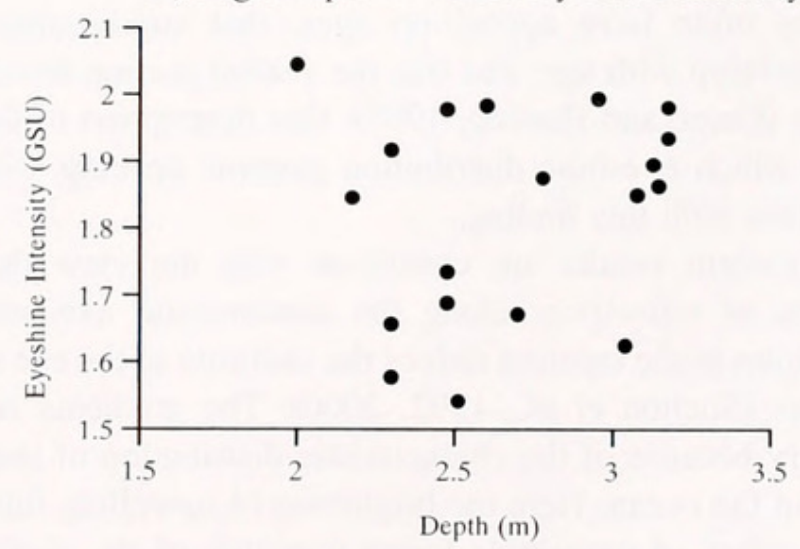

Figure 3. Eyeshine intensity in relation to depth distributions for adult mesopelagic species $(n=19)$ with least-squares lines fitted. Significant positive correlations were found for dorsal eyeshine intensity and day depth [(a) $r=0.68, P<0.001]$ and night depth [(b) $r=0.81, P<0.001]$. When Oplophorus spinosus (O.s in Fig. 3a) - which exhibits higher dorsal eyeshine intensity than expected for its estimated daytime depth distribution-is excluded, $r=0.82$. Ventral eyeshine intensity was poorly correlated with both day [(c) $r=0.34$, n.s. $]$ and night [(d) $r=0.17$, n.s.] depths. 
dorsal eyeshine was brighter, and the difference in intensity between dorsal and ventral regions of the eye decreased. In all species examined except Systellaspis debilis and Notostomus auriculatus, eyeshine intensity in at least one region of the eye increased with carapace length. Ventral eyeshine showed no significant depth-related trend. The variation in eyeshine distribution suggests that dorsal eyeshine intensity is related to the degree to which each shrimp species is exposed to downwelling light. This is supported by theoretical evidence which suggests that for any given eye, there are ideal distributions of reflecting and shielding pigments that optimize both sensitivity and resolution (Warrant and McIntyre, 1991). For most superposition compound eyes, the tapetum should, ideally, be formed of reflecting pigment enclosing the proximal third of each rhabdom. This has the effect of doubling the path length of light (by reflecting unabsorbed photons back through the target rhabdom) and restricting the bleed of light between adjacent rhabdoms. Despite the prevailing low levels of ambient light normally experienced by mesopelagic species, the distributions of these pigments generally deviate from the theoretical ideal (for maximum sensitivity) in the dorsal part of the eye (Gaten et al., 1992; Johnson, 1998). This suggests that there is a requirement to remain camouflaged that outweighs the need for highly sensitive vision dorsally.

Generally we have found that with increasing carapace length, eyeshine intensity increases, and that the increase is more pronounced dorsally than ventrally. If the supposition that dorsal eyeshine intensity is determined by habitat depth is true, then it follows that where eyeshine increases with carapace length, juvenile mesopelagic decapods should be found closer to the surface than adults. Size-related differences in vertical distribution have been observed for some mesopelagic decapods, euphausiids, and copepods (Foxton, 1970; Baker, 1970; Hays, 1996). The study of the ontogeny of eye anatomy of mesopelagic decapods has shown that juveniles often have apposition eyes, that superposition optics develop with age, and that the ventral portion develops first (Gaten and Herring, 1995). Our description of the way in which eyeshine distribution patterns develop with size agrees with this finding.

The current results are consistent with the view that gradients of reflectivity along the dorsoventral axis and dorsal holes in the tapetum reduce the visibility of the eye to predators (Shelton et al., 1992, 2000). The gradients are necessary because of the characteristic distribution of irradiance in the ocean. Here the brightness of upwelling light is two orders of magnitude lower than that of the downwelling light, and the light field is symmetrical about the vertical axis (Kirk, 1983). Low reflectivity in upwardly looking parts of the eye reduces the contrast between the light reflected from the tapetum and that arising from the dim background. In downwardly looking parts of the eye, a highly reflective ventral tapetum is unlikely to increase visibility, because the levels of upwelling light are low.

The variations in eyeshine distribution shown here are an example of how the development of sense organs can be linked, in a functional manner, to variations in depth distribution. Small decapods can only have small eyes and are limited in the degree to which they can vertically migrate by the inverse relationship between body size and energy requirements for swimming (Longhurst, 1976). A small apposition eye is sufficient in the relatively well-lit upper regions of the pelagic realm, where juvenile and adolescent pelagic decapods and euphausiids are to be found (Baker, 1970; Foxton, 1970; Marshall, 1979), but as shrimps increase in size and daily movement to the ecological refuge provided by depth (King and Butler, 1985) becomes a viable strategy, their eyes develop to suit a more oligophotic environment.

\section{Acknowledgments}

We gratefully acknowledge the assistance given by the officers and crew of RRS Discovery and Tony Rice of Southampton Oceanography Centre for allowing MLJ to participate in cruise 204. Many thanks also to Jeremy Brooks for technical assistance with eyeshine measurements and to Matt Sheehy for his comments on the manuscript. MLJ was supported by NERC grant GT4/92/5/A. PMJS and PJH acknowledge support of NERC grants GR9/0019A and GR3/11212.

\section{Literature Cited}

Baker, A. de C. 1970. The vertical distribution of euphausiids near Fuerteventura, Canary Islands ('Discovery' SOND Cruise, 1965). $J$. Mar. Biol. Assoc. UK 50: 301-342.

Burkenroad, M. D. 1943. A possible function of bioluminescence. $J$. Mar. Res. 5: 161-164.

Cartes, J. E., J. C. Sorbe, and F. Sardà. 1994. Spatial distribution of deep-sea decapods and euphausiids near the bottom in the northwestern Mediterranean. J. Exp. Mar. Biol. Ecol. 179: 131-144.

Crosnier, A., and J. Forest. 1973. Les Crevettes Profondes de L'Atlantique Oriental Tropical, Volume XIX. ORSTOM, Paris.

Domanski, P. A. 1985. The Azores front: a zoogeographic boundary? UNESCO Tech. Pap. Mar. Sci. No. 49: 73-83.

Foxton, P. 1970. The vertical distribution of pelagic decapods (Crustacea: Natantia) collected on the Sond Cruise 1965. J. Mar. Biol. Assoc. UK 50: $939-960$.

Gaten, E., and P. J. Herring. 1995. Morphology of the reflecting superposition eyes of larval oplophorid shrimps. J. Morphol. 225: 19-29.

Gaten, E., P. M. J. Shelton, and P. J. Herring. 1992. Regional morphological variations in the compound eyes of certain mesopelagic shrimps in relation to their habitat. J. Mar. Biol. Assoc. UK 72: 61-75.

González, J. A., M. V. Tuset, I. J. Lozano, and J. I. Santana. 1997. Biology of Plesionika narval (Crustacea, Decapoda, Pandalidae) around the Canary Islands (Eastern Central Atlantic). Est. Coast Shelf Sci. 44: $339-350$.

Hays, G. C. 1996. Large-scale patterns of diel vertical migration in the North Atlantic. Deep-Sea Res. 43: 1601-1615. 
Heffernan, J. J., and T. L. Hopkins. 1981. Vertical distribution and feeding of the shrimp genera Gennadas and Bentheogennema (Decapoda: Penaeidea) in the eastern Gulf of Mexico. J. Crustac. Biol. 1: $461-473$.

Herring, P. J. 1990. Bioluminescent communication in the sea. Pp. 245-278 in Light and Life in the Sea, P. J. Herring, A. K. Campbell, M. Whitfield, and L. Maddock, eds. Cambridge University Press, Cambridge.

Herring, P. J., and H. S. J. Roe. 1988. The photoecology of pelagic oceanic decapods. Symp. Zool. Soc. Lond. 59: 263-290.

Hiller-Adams, P., and J. F. Case. 1988. Eye size of pelagic crustaceans as a function of habitat depth and possession of photophores. Vision. Res. 28: $667-680$.

Jerlov, N. G. 1974. Significant relationships between optical properties of the sea. Pp. 77-94 in Optical Aspects of Oceanography, N. G. Jerlov, ed. Academic Press, London.

Johnson, M. L. 1998. Aspects of visual function and adaptation of deep-sea decapods. Ph.D. Thesis, University of Leicester, Leicester, England. 262 pp.

Johnson, M. L., P. M. J. Shelton, and E. Gaten. 2000. Temporal responses in the eyes of marine decapods from coastal and deep sea habitats. Mar. Biol. 136: 243-248.

King, M. G., and A. J. Butler. 1985. Relationship of life history patterns to depth in deep-water caridean shrimps (Crustacea: Natantia). Mar. Biol. 86: $129-138$.

Kirk, J. T. O. 1983. Light and Photosynthesis in Aquatic Ecosystems. Cambridge University Press, Cambridge.

Kunze, P. 1979. Apposition and superposition eyes. Pp. 441-502 in Handbook of Sensory Physiology, H. Autrum, ed. Springer-Verlag, Berlin.

Land, M. F. 1981. Optics and vision in invertebrates. Pp. 471-492 in Handbook of Sensory Physiology, H. Autrum, ed. Springer-Verlag, Berlin.

Laughlin, S. B., and M. Weckström. 1993. Fast and slow photoreceptors - a comparative study of the functional diversity of coding and conductances in the Diptera. J. Comp. Physiol. A 172: 593-609.

Longhurst, A. R. 1976. Vertical migration. Pp. 116-137 in The Ecology of the Seas, D. H. Cushing and J. J. Walsh, eds. Blackwell Scientific, Oxford.
Lythgoe, J. N. 1979. The Ecology of Vision. Oxford University Press, Oxford.

Marshall, N. B. 1979. Developments in Deep-Sea Biology (Blandford Press, Poole, England.

Morin, J. G., and A. C. Cohen. 1991. Bioluminescent displays, courtship and reproduction in ostracodes. Pp. 1-16 in Crustacean Sexual Biology, T. B. J. Martin, ed. Columbia University Press, New York.

Nilsson, H. L. 1982. Rhabdom breakdown in the eye of Cirolana borealis (Crustacea) caused by exposure to daylight. Cell Tissue Res. 227: 633-639.

Nilsson, H. L., and M. Lindström. 1983. Retinal damage and sensitivity loss of a light-sensitive crustacean compound eye (Cirolana borealis). J. Exp. Biol. 107: 277-292.

Roe, H. S. J. 1984. The diel migrations and distributions within a mesopelagic community in the north east Atlantic. 2. Vertical migrations and feeding of mysids and decapod crustacea. Prog. Oceanogr. 13: $269-318$

Roe, H. S. J., and D. M. Shale. 1979. A new multiple rectangular mid-water trawl (RMT $1+8 \mathrm{M}$ ) and some modifications to the Institute of Oceanographic Sciences' RMT $1+8$. Mar. Biol. 50: 283-288.

Shelton, P. M. J., E. Gaten, and C. J. Chapman. 1986. Accessory pigment distribution and migration in the compound eye of Nephrops norvegicus (L.) (Crustacea: Decapoda). J. Exp. Mar. Biol. Ecol. 98: 185-198.

Shelton, P. M. J., E. Gaten, and P. J. Herring. 1992. Adaptations of tapeta in the eyes of mesopelagic shrimps to match the oceanic irradiance distribution. J. Mar. Biol. Assoc. UK 72: 77-88.

Shelton, P. M. J., E. Gaten, M. L. Johnson, and P. J. Herring. 2000. The 'eye-blink' response of mesopelagic Natantia; eyeshine patterns and the escape reaction. Crustacean Issues 12: 253-260.

Warrant, E. J., and P. D. McIntyre. 1991. Strategies for retinal design in arthropod eyes of low F-number. J. Comp. Physiol. A 168: 499512 .

Wild, R. A., E. Darlington, and P. J. Herring. 1985. An acoustically controlled cod-end system for the recovery of deep-sea animals at in situ temperatures. Deep-Sea Res. 32: 1583-1589. 

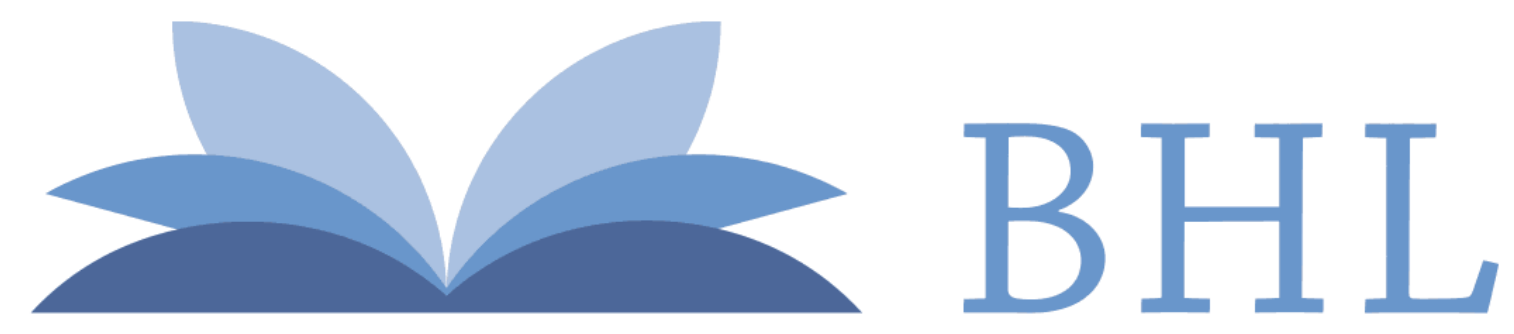

\section{Biodiversity Heritage Library}

Johnson, M L et al. 2000. "Relationship of dorsoventral eyeshine distributions to habitat depth and animal size in mesopelagic decapods." The Biological bulletin 199, 6-13. https://doi.org/10.2307/1542701.

View This Item Online: https://www.biodiversitylibrary.org/item/17162

DOI: https://doi.org/10.2307/1542701

Permalink: https://www.biodiversitylibrary.org/partpdf/10556

\section{Holding Institution}

MBLWHOI Library

\section{Sponsored by}

MBLWHOI Library

\section{Copyright \& Reuse}

Copyright Status: In copyright. Digitized with the permission of the rights holder.

License: http://creativecommons.org/licenses/by-nc-sa/3.0/

Rights: https://biodiversitylibrary.org/permissions

This document was created from content at the Biodiversity Heritage Library, the world's largest open access digital library for biodiversity literature and archives. Visit BHL at https://www.biodiversitylibrary.org. 